\title{
THE POLITICAL AND LEGAL ASPECTS OF CHANGE OF SOVEREIGNTY.
}

It is an interesting coincidence that the two treaties which mark a turning point in the domestic and foreign policy of the United States should both have been negotiated in the French capital and should both be known as Treaties of Paris. Although the territory acquired by the treaty of I 899

- cannot compare, either in area or value, with the acquisition of 1803 , its probable influence on the institutional life and public policy of the country entitles it to a position of almost equal significance.

The ratification of both treaties was followed by protracted constitutional discussions, first as to power of the United States government to acquire territory and then as to the imitations on congressional action in dealing with the inhabitants. The controversies of 1803 were not set at rest until the decision of the highest Federal tribunal settled the disputed questions. The treatment of the territory acquired by the treaty of 1899 has aroused differences of opinion no less marked which have not been reconciled by the opinions of the Supreme Court in the insular cases. This is due, in part, to the unprecedented division of opinion amongst the justices, but mainly to the failure of the decisions to answer clearly and definitely some of the most important constitutional questions involved in the controversy.

American Insurance Co. v. Canter, ${ }^{1}$ set at rest all doubt as to the constitutional power of the United States to acquire territory-a power which rests upon no specific constitutional provision but is incident to and inherent in the existence of the United States as a sovereign nation. The conditions under which such territory may be held, the relation of the constitutional privileges, requirements and limitations to the inhabitants, and the power of Congress in dealing with the population are all questions to which the Supreme Court had given no definite answer, owing to the fact that the

I Peters, 542. 
specific points at issue in the recent cases had never before been presented for adjudication. It is true that in a number of opinions incidental questions were adjudicated, which furnish a background of precedent, but even these precedents are valuable as an indication of the attitude of the court rather than final adjudications of the questions involved.

In addition to these constitutional questions, some of which were passed upon in the insular cases, the ratification of the treaty of Paris brought up a number of legal questions -international and domestic-presenting peculiar difficulties. The overthrow of the Spanish government by the invading army of the United States, placed the island in possession of the military authorities. In the exercise of the right accorded by international law to every belligerent, a provisional government was established for the purpose of maintaining social order and securing respect for person and property.

In administering civil affairs, as an obligation incident to belligerent occupation, the power of the military commanders is free from constitutional limitations on executive, legislative and judicial power. During this period the territory does not become part of the United States. In Fleming v. Page, ${ }^{2}$ the Supreme Court of the United States, speaking of the status of Tampico during its belligerent occupation by United States troops said: "The boundaries of the United States as they existed when war was declared against Mexico were not extended by the conquest; nor could they be regulated by the varying incidents of war and be enlarged or diminished as the armies on either side advanced or retreated. They remained unchanged and every place which was out of the limits of the United States as previously established by the political authorities of the government, was still foreign." As a matter of public policy, military governments thus established have usually allowed the domestic institutions of the occupied or conquered country to remain untouched, especially when not in flagrant conflict with the institutions and political standards of the conquering country. In fact the "Instructions for the Gov-

${ }^{2} 9$ Howard, 6r6. 
ernment of Armies of the United States in the Field,"3 provide that "all civil and penal law shall continue to take its usual course in the enemy's places and territories under martial law, unless interrupted or stopped by order of the occupying military power; but all the functions of the hostile government-legislative, executive or administrativewhether of a general, provincial or local character, cease under martial law, or continue only with the sanction, or if deemed necessary, the participation of the occupier or invader."

The moment the invaded territory ceases to be the theatre - of military operations the authority of the military government becomes subject to important limitations. The complete dependence of individual rights on the will of the military commander ceases, and his acts become subject to certain rules of law which the courts have not hesitated to enforce. Of these the most important is the rule of "immediate exigency" or "necessity.". When, during the Reconstruction Period, the military governors attempted to set aside judicial decrees the Supreme Court held that "it is an unbending rule of law, that the exercise of military power where the rights of the citizens are concerned shall never be pushed beyond what the exigency requires."4

The ratification of the treaty of Paris on the eleventh of April, I899, and the formal transfer of sovereignty did not affect the existence of the military government, although it served still further to limit its powers. It is evident that the change of dominion alone contributed nothing towards the establishment of a new government to replace the old. The same principle of overruling necessity which explains the necessity for the establishment of military government justifies its continued existence until replaced by some form of civil rule. On this point there has been complete harmony of practice and opinion in the executive, legislative and judicial branches of the government. Military government was continued over New Mexico and California for a considerable period after the treaty of peace with Mexico. President Polk,

\footnotetext{
${ }^{3}$ General Order I00, A. G. O. 1863.

- Raymond v. Thomas,-9r U. S. 712.
} 
in his message of December 5,1848 , justified this policy in the fcllowing terms: "The only government which remained was that established by the military authority during the war. Regarding this to be a de facto government, and that by the personal consent of the inhabitants it might be continued temporarily, they were advised to conform and submit to it for the short intervening period before Congress would again assemble and could legislate upon the subject." The first clear judicial adjudication of this question was made by the Supreme Court of the United States in Cross v. Harrison. ${ }^{5}$ The question at issue was the validity of certain.customs duties collected on goods coming into California, and involved, incidentally, the authority of the military governor to impose such duties after the ratification of the treaty of peace. Referring to the continued existence of the military government after the exchange of ratifications the Court said: "The President might have dissolved it by withdrawing the army and navy officers who administered it, but he did not do so. Congress could have put an end to it, but that was not done. The right inference from the inaction of both is that it was meant to be continued until it had been legislatively changed. No presumption of a contrary intention can be made. Whatever may have been the causes of delay, it must be presumed that the delay was consistent with the true policy of the government; and the more so, as it was continued until the people of the territory met in convention to form a state government, which was subsequently recognized by Congress under its power to admit new states into the Union."

While its existence may thus be continued, the status of the military government undergoes some change throiugh the ratification of the treaty of peace. Prior to this time a state of war constructively exists and the military government is merely a substitute for the displaced authorities. After the ratification of the treaty, the military government represents the nezv sovereignty, ${ }^{6}$ and its action can no longer

"I6 Howard, 164 .

- This distinction has been clearly set forth in the valuable compilation of the reports of the law officer of the War Department, Charles E. Magoon, Esq. 
rest upon military exigency. It becomes a provisional civil authority, entrusted with the task of maintaining order, protecting the public health and promoting the administration of the internal affairs of the country. The substitution of the civil for the military code is no longer a matter of choice. The action of the military authorities must conform to the fundamental principles of free government and respect for individual rights, the summary methods of martial rule being no longer permissible. In ex parte Milligan, the distinction between the two kinds of military jurisdiction was clearly pointed out. The case involved the validity of a con- viction by a military court held in the state of Indiana during the civil war. "If, in foreign invasion or civil war, the courts are actually closed and it is impossible to administer criminal justice according to law, then on the theatre of active military operations, where war really prevails, there is a necessity to furnish a substitute for the civil authority thus overthrown to preserve the safety of the army and society, and as no power is left but the military, it is allowed to govern by martial rule until the laws can have their free course. As necessity creates the rule, so it limits its duration; for if this government is continued after the courts are reinstated, it is a gross usurpation of power. Martial rule can never exist where the courts are open and in the proper and unobstructed exercise of their jurisdiction. It is also confined to the locality of actual war."

In one of the recent insular cases-Dooley v. United Siates, ${ }^{8}$-the Supreme Court laid down a principle which places a further limitation on the power of the military authority as soon as the treaty of peace is ratified. Com- . menting on the customs dues imposed on articles coming into Porto Rico from the United States after the eleventh of April, I899, the Court says: "The spirit as well as the letter of the tariff laws admits of duties being levied by a military commander only upon importations from foreign countries; and while his power is necessarily despotic, this must be understood rather in an administrative than in a legislative sense. While in legislating for $a$ conquered country he may

${ }^{4} 4$ Wallace, 2.

I82 U. S. 222. 
disregard the laws of that country, he is not wholly above the laws of his own. . . . His power to administer would be absolute, but his power to legislate would not be without certain restrictions-in other words, they would not extend beyond the necessities of the case." While the expressions used by the Court are somewhat vague, they were intended undoubtedly to convey the meaning that the power of the military commander is unlimited in prescribing administrative rules to meet immediate exigencies or in adapting native institutions to American standards, but in the determination of the public policy of the territory under military rule, no step contrary to the general legislative policy of the United States can be taken.

Before leaving this phase of the subject it may be well to point out the peculiar situation in the Philippine Islands, due to the fact that coincident with the change of sovereignty the United States government had to deal with an insurrectionary movement which threatened to postpone, for an indefinite period, the introduction of civil rule. The continuance of the armed conflict, furthermore, prevented the treaty of peace from having its full effect on the personal. rights and immunities of the inhabitants. But the fact that certain districts not only welcomed American rule but were co-operating with the authorities in improving conditions in the islands, made the government feel inclined to extend to such districts the full benefits of civil rule. To effect this purpose without seriously interfering with the authority of the military officers in the disturbed provinces required the formulation of a new theory of military rule, or at least a new series of distinctions as to the elements which compose it. The Secretary of War proved himself fully equal to the task and in his effort was seconded by Congress and the President.

The view taken by the Secretary of War was that the military power vested in the President as commander-inchief of the military and naval forces of the United States embraces executive, legislative and judicial functions. Not only is a separation of these functions possible but they may each be exercised by a different group of officials. It is also a well settled principle that this military power of the Presi- 
dent may be exercised through civil agents as well as by military officers. As stated by the Secretary of War in his report for I90I: "The military power when exercised in a territory under military occupation includes executive, judicial and legislative authority. It not infrequently happens that in a single order of a military commander can be found the exercise of all three of these different powers-the exercise of the legislative power by provisions prescribing a rule of action, of judicial power by determinations of right, and of executive power by the enforcement of the rules prescribed and the rights determined."

This division of authority paved the way for the appointment of the Philippine Commission. which was vested with "that part of the military power of the -President in the Philippines which is legislative in its character." The executive authority in civil affairs was retained by the military governor in order to assure the ready and prompt action which the exceptional situation demanded. - Judicial power was vested in such courts as the Commission, in the exercise of its legislative power, might create. A1though nominally exercising legislative powers, the Commission enjoyed important executive functions. Thus, under the instructions issued by the President August 7, I $900,{ }^{10}$ the Commission was given power "to appoint to office such officers under the judicial, educational and civil-service systems and in the municipal and departmental governments as shall be provided for."

It was felt by the administration that the injection of the civil element into the military government would soften the rigors of the latter and would tend to bring the administration of the affairs of the islands into closer harmony with American standards of liberty. While this end was undoubtedly attained, the peculiar division of power gave rise to friction between the Commission and the military authorities, which threatened to reduce considerably the useftulness of the former. In order to pave the way for the complete establishment of civil government, the Spooner amendment to the army appropriation bill was passed (March 2, I9or),

- Report, Secretary of War (I900), p. 25.

1s R.eport of Secretary of War (1900). Appendix B, p. 70 
which provides that "all military, civil and judicial powers necessary to govern the Philippine Islands . . . shall, until otherwise provided by Congress, be vested in such person and persons and shall be exercised in such manner as the President of the United States shall direct for the establishment of civil government and for maintaining and protecting the inhabitants of said islands in the free enjoyment of their liberty, property and religion." This amendment made it possible for the President to make such adjustments between the civil and military authorities as the exigencies of the situation required. In the districts completely pacified the civil authority was made supreme; wherever disturbances were still threatened the military government remained in undisturbed control. The final step in the establishment of civil government was made by the Philippine Civil Government Act of July I, I902. Thus, owing to the insurrectionary movement, the ratification of the treaty of peace did not have quite the same legal effects in the Philippines as in Porto Rico. The unrestricted authority of the military commander was continued for a much longer period.

It remains now to consider the effect of the treaty of Paris on the laws and institutions of the ceded territory and on the political rights and civil status of its inhabitants. The clauses ceding Porto Rico and the Philippines transferred to the United States complete political power over the islands together with all the property and interests possessed therein by Spain. ${ }^{11}$

In the course of the negotiations at Paris, the Spanish Commissioners insisted that the United States assume the indebtedness contracted by Spain in the interest and for the benefit of the ceded territory. To this the American representatives refused to accede. Under the rules of international law such obligation does not pass unless specifically so provided in the treaty of cession. The situation with reference to the indebtedness of municipalities and other local subdivisions is somewhat different. They are corporations with obligations of a quasi-private nature which remain unaffected by the change of sovereignty. In fact it becomes the duty 197.

${ }^{11}$ Cf. Josephs v. U. S. Court of Clains (1865). I Court of Claims, 
of the new sovereign to hold the local governments to a strict observance of their contractual obligations.

In ordinary circumstances the effects of a transfer of territory upon local laws and upon the political and civil rights of the inhabitants are dependent upon two circumstances ; first, the general principles of international law, and secondly, the specific provisions of the treaty of cession. Under our system of government a third factor must be added, viz: the provisions of the Constitution. It is a well-settled principle of law that the change of sovereignty does not affect those portions of the local law that regulate the personal and property relations of the inhabitants inter se. All laws of a political or administrative character, however, which are not in harmony with the institutions of the new sovereignty are abrogated. They lose their force and effect by the fact of transfer of sovereignty and require no positive action on the part of the new government. The theory upon which this principle rests is that sudden changes in the private law would work great injustice to innocent parties and would tend to complicate the problem of government by arousing the antagonism of the inhabitants of the ceded territory. On the other hand the new sovereign cannot permit the continued existence of institutions which are hopelessly at variance with the genius and character of its political system. To do this requires affirmative action indicating an evident intent to preserve the political institutions of the displaced sovereignty.

The rules of law governing the question were clearly presented in the Chicago R. I. \& P. R'y Co. v. McGlinn.12 "It is a general rule of public law, recognized and acted upon by the United States, that whenever political jurisdiction and legislative power over any territory are transferred from one. nation or sovereign to another, the municipal laws of the country, that is, laws which are intended for the protection of private rights, continue in force until abrogated or changed by the new government or sovereign. By the cession, public property passes from one government to the other. but private property remains as before, and with it those

${ }_{\text {II4 U. S. 542, } 546 .}$ 
municipal laws which are designed to secure its peaceful use and enjoyment. As a matter of course, all laws, ordinances, and regulations in conflict with the political character, institutions and constitution of the new government are at once displaced. Thus, upon a cession of political jurisdiction and legislative power-and the latter is involved in the formerto the United States, the laws of the country in support of an established religion, or abridging. the freedom of the press, or authorizing cruel and unusual punishments, and the like, would at once cease to be of obligatory force without any declaration to that effect; and the laws of the country on other subjects would necessarily be superseded by existing laws of the new government upon the same matters."

While the general principle involved is perfectly clear, its application, at times, is extremely difficult. But a short time ago the Supreme Court of Porto Rico was called upon to determine whether the Spanish Press Law of November II, I886, in force in Porto Rico was abrogated by reason of the change of sovereignty. In this case the Court (per. Justice McLeary), held that the first amendment to the Constitution prohibiting Congress from making any law abridging the freedom of the press was in force in Porto Rico. In deciding the point at issue it was hardly necessary for the Court to take this advanced position. All the requirements of the situation would have been met if the Court had held closely to the principle laid down in $R$. R. Co. v. McGlinn, viz: that the law in question was in direct antagonism with one of the fundamental principles of American liberty-the freedom of the press.

From what has been said it must not be inferred that the political laws of the displaced sovereignty cannot be continued in force. To effect this purpose, however, an express declaration by the new sovereignty is necessary. Thus, at the time of the occupation of Porto Rico the laws relating to local government were continued in force by the military governor and in the Organic Act of April 12, I900, it was provided that "the laws and ordinances of Porto Rico now in force shall continue in full force and effect, except as altered, amended or modified hereinafter, or as altered or modified by military orders and decrees in force when this act shall take effect." 
476 THE POLITICAL AND LEGAI ASPECTS, ETC.

Were no constitutional questions involved, the political and civil status of the inhabitants of newly acquired territory would be solved without difficulty. The general rule of international law is that a transfer of territory implies a transfer of allegiance unless the treaty of cession contains some provision to the contrary. In the treaty with Spain the option of retaining Spanish nationality was limited to Spanish subjects, natives of the mother country. The civil rights and political status of the native-born inhabitants of Porto Rico and the Philippines were left to the subsequent determination of Congress. The content of this reserved power, in fact its constitutionality, depends upon the legal effects of a treaty of cession. If newly acquired territory is thereby made part of the United States within the meaning of the Constitution, the political status, and to a very large extent the civil rights, of the inhabitants are determined by the Constitution. The questions here involved we must reserve for subsequent treatment.

- The rules of international law with reference to the property rights of inhabitants of ceded territory are clear and definite and have been consistently adhered to by the Supreme Court. 'In United States v. Percheman, ${ }^{13}$ Chief Justice Marshall in interpreting the eighth article of the treaty of I8Ig with Spain, held that even in the absence of a treaty stipulation the private property of inhabitants of the ceded territory would be fully protected. "The people change their allegiance . . . but their relations to each other, and their rights of property, remain undisturbed."

University of Pennsylvania.

L. S. Rozve.

27 Peters, 5I. 